\title{
Evaluation of large deformations on Romanesque masonry pillars: The case of Santa María de Arties (XII-XIII) at Valle de Arán, Spain
}

\author{
Análisis de grandes deformaciones en pilares de obra de fábrica románicos: el caso de Santa María \\ de Arties (XII-XIII) en el Valle de Arán, España
}

\author{
Josep Lluis i Ginovart (Main and Corresponding Author) \\ Universitat Internacional de Catalunya (UIC) \\ C/ Immaculada 22, 08017 Barcelona (Spain) \\ jlluisg@uic.es

\section{Sergio Coll-Pla} \\ Universitat Rovira i Virgili (URV) \\ Av/ Universitat 1, 43204 Reus (Spain) \\ sergio.coll@urv.cat \\ Agustí Costa-Jover \\ Universitat Rovira i Virgili (URV) \\ Av/ Universitat 1, 43204 Reus (Spain) \\ agusti.costa@urv.cat \\ Mónica López Piquer \\ Universitat Internacional de Catalunya (UIC) \\ C/ Immaculada 22, 08017 Barcelona (Spain) \\ mlopezp@uic.es
}

Manuscript Code: 810

Date of Acceptance/Reception: 12.11.2017/09.09.2016

DOI: $10.7764 / R D L C .16 .3 .468$

\begin{abstract}
There is a set of Romanesque churches at Valle de Aran that were built between the eleventh and thirteenth centuries; these churches have suffered large deformations and geometrical displacements. These deformations have provoked, in some cases, convex shapes to appear, in relation to the generatrix of the vaults, which have the inverted shape of an arch. Geometrical assessment of the least rigid elements, the pillars, makes it possible to analyse the displacements, which have been the cause of funicular shapes on some vaults. It is possible to deduce the regression plane of the displacements of the pillars of the central nave and to define the deformation vectors over it. Thus, these data reveal the directions of the deformations of vaults and pillars to be determined. The deformations of the pillars are not perpendicular to the directrix of the central vault, so the methodology and results can be very useful to understand the nature of the displacements and to maintain these masonry structures.
\end{abstract}

Key words: Romanesque, masonry, barrel vault, pillar, great deformations, Valle de Arán.

\section{Resumen}

En el Valle de Arán existe un conjunto de iglesias románicas que fueron construidas entre los siglos XI y XIII; estas iglesias han sufrido grandes deformaciones y desplazamientos geométricos. Estas deformaciones han provocado que, en algunos casos, que aparezcan formas convexas, en relación con la generatriz de las bóvedas, que tienen la forma invertida de un arco. La evaluación geométrica de los elementos menos rígidos, los pilares, permite analizar los desplazamientos, que han sido la causa de las formas funiculares en algunas bóvedas. Es posible deducir el plano de regresión de los desplazamientos de los pilares de la nave central y definir los vectores de deformación sobre ella. Así, esta información permite determinar la dirección de las deformaciones de bóvedas y pilares. Las deformaciones de los pilares no son perpendiculares a la directriz de la bóveda central, por lo que la metodología y los resultados pueden ser muy útiles para comprender la naturaleza de los desplazamientos y para mantener estas estructuras de mampostería.

Palabras clave: Románico, obra de fábrica, bóveda de cañón, pilar, grandes deformaciones, Valle de Arán.

Introduction and Description of the problem

\section{The great deformations of the Valle de Aran Romanesque}

The churches of Valle de Aran are located at the Spanish Pyrenees and were built between twelfth and thirteenth centuries. One of the main features of these buildings is the large deformations of the masonry structure. One of the most deformed buildings is the church of Santa Maria de Arties (XII) (Figure 1), which is a basilica floor plan with a central 
nave and two collaterals, each with four bays. The central pillars support the formerets under the barrel vault and the lateral half-vaults that supports over perimeter walls. The heading is currently finished with a semicircular apse, reconstructed during last years, and the two original apsidioles. All of them are covered with hemispherical domes.

The structure presents a typical deformation pattern: leaning of vertical elements towards the outside because of vaults thrust, and settlement of vaults, which have caused the apparition of funicular shapes, which is the inverse of the natural shape of an arch since it is convex in relation to its generatrix. One of the causes of these deformations is the displacement of the pillars since these are the least rigid elements of the structure. The investigation focuses on the geometrical parametrization and evaluation of these movements. Previous investigations focused on the assessment of the overall structure, in order to understand the stability conditions (Costa-Jover, Lluis i Ginovart, Fortuny-Anguera, \& Coll-Pla, 2014; Costa Jover \& Coll Pla, 2017), which revealed that masonry is working to the limit due to the deformations suffered, while the origin of the movements can be explained by rigidity issues.

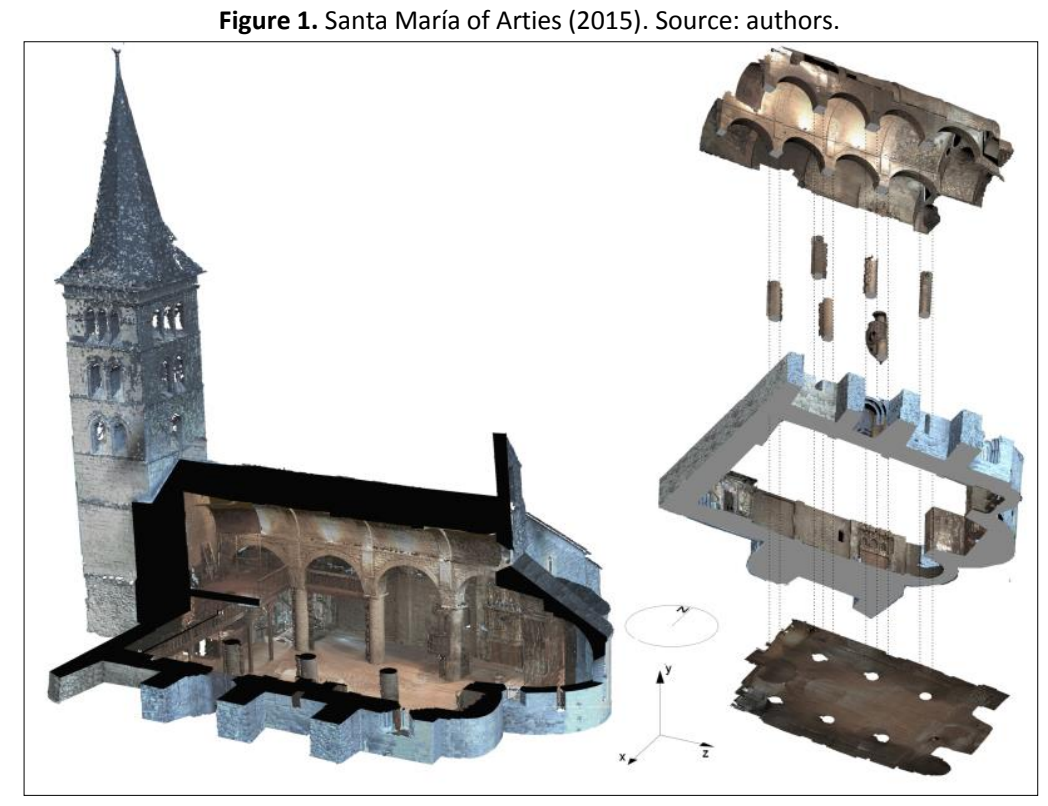

State of the Art

Due to the large deformations, these Romanesque constructions were assessed by several authors, such as Emmanuel Viollet-le-Duc (1814-1879), who visited Bossost (1883) (Español, 2011), and later by Lluís Domènech i Montaner (18501923), who was Dean of the Escuela de Arquitectura de Barcelona (1905) (Granell \& Ramon, 2006). Subsequently, the Institut d'Estudis Catalans organized an expedition with the combined historical and archaeological purpose of visiting the Valle de Aran and La Ribagorça (1907). Two of the participants were the architects Josep Puig i Cadafalch (18671956) and Josep Goday i Casals (1881-1936) (Alcolea Blanch, 2008), who suggested that these churches were initially covered with timber structures, which were later replaced by masonry barrel vaults (Puig i Cadafalch, 1908).

Juan Bassegoda i Nonell (1930-2012) stated that formal anomalies are a defining characteristic of the Catalan Romanesque architecture (Bassegoda, 1974). The case study presented in this paper focuses on the church of Santa Maria d'Arties, which is the most assessed building of this group. Its great deformations were identified during the restoration work of the 70s (Bassegoda, 1972; Saez, 1976). Afterwards, José Luis Villanueva i noted the existence of the funicular shapes (Villanueva, 1974), and in 2009, the structure was assessed by means of finite elements (FEM) by the team of Joan Polo i Berroy (Polo, 2009).

Otherwise, the architectural heritage topographic documentation is a key tool for its preservation. Current techniques of Massive Data Capture (MDC), such as digital photogrammetry and terrestrial laser scanner, have become widespread in the assessment of built heritage (Kadobayashi, Kochi, Otani, \& Furukawa, 2004; Yilmaz, Yakar, Gulec, \& Dulgerler, 2007). Numerous investigations have tested the technique's reliability (Grussenmeyer, Landes, Voegtle, \& Ringle, 2008), (Vendrell, Giráldez, González, Cavallé, \& Roca, 2008), and has proven their effectiveness to survey the building's geometry with high precision. The point clouds make it possible to detect and monitor degradation processes and formal anomalies. Other applications goes from heritage documentation (Dhonju, Xiao, Shakya, Mills, \& Sarhosis, 2017; H. K. Dhonju, W. Xiao, V. Sarhosis, J. P. Mills, S. Wilkinson2 Z. Wang, L. Thapa, 2017) to deepen in the history and buildings constructions (Benito, 2011; Sternberg, 2006) between many others. 
The specific issue of deformation assessment is essential for architectural heritage conservation, and many studies have developed simple procedures to address that issue from the 3D topographical information of the point clouds, i.e. the Cathedral of St. Johannis in Meldorf (Quagliarini, Clini, \& Ripanti, 2016), the churches of Santa Maria in Portonovo (Bonali, Pesci, Casula, \& Boschi, 2014) and Cantalovo (Pesci, Bonali, Galli, \& Boschi, 2012) or the Palazzo d'Accursio (Costa-Jover, Lluis i Ginovart, Fortuny-Anguera, \& Coll-Pla, 2014; Costa Jover \& Coll Pla, 2017), all in Italy. Those investigation focuses on the assessment of vertical elements deformations, except the Portonovo's case, where a simple assessment of the cylindrical barrel vaults is performed from standard primitives.

Methodology

\section{Theoretical framework: systematization of the deformations on vaults and pillars}

In order to establish the general theoretical framework, the assessment of the shapes can only be understood in three dimensions. From the point of view of historiography, Emmanuel Viollet-le-Duc (1814-1879) assessed the barrel vaults and the abutment with timber beams with precision (Viollet-le-Duc, 1868). Afterwards, August Choisy (1841-1909) did not explain the Romanesque vaults, but did explain the origin of barrel vaults from Roman construction with brick and concrete (Auguste Choisy, 1873). He referred to the byzantine influence on construction with or without centering (A Choisy, 1883). Otherwise, in the work Historia General del Arte (1901), Josep Puig i Cadafalch described the great difference between the Romanesque vaults, where stability is the main concept inherited from roman vaults, which were significantly more monolithic (Puig i Cadafalch, 1901).

When the geometry of these vaults is regular and the construction is monolithic due to the masonry configuration, the thrust is perpendicular to the central guideline of the vault. Conversely, barrel vaults of Valle de Aran churches have specific features. These are conical vaults, as was theorised by Joan Bassegoda (1974), and the stone-cutting is not regular, as stated by Josep Puig i Cadafalch (1901). Finally, the supports of the vaults, external walls and arches, have different stiffness, as noted by Luis Villanueva (1974). Those three conditions are far from the general theory of the thrust of homogeneous vaults with cylindrical guideline. In addition, the assessment of the pillar deformations and their stiffness is influenced by the contributions of Josep Puig i Cadafalch (1908).

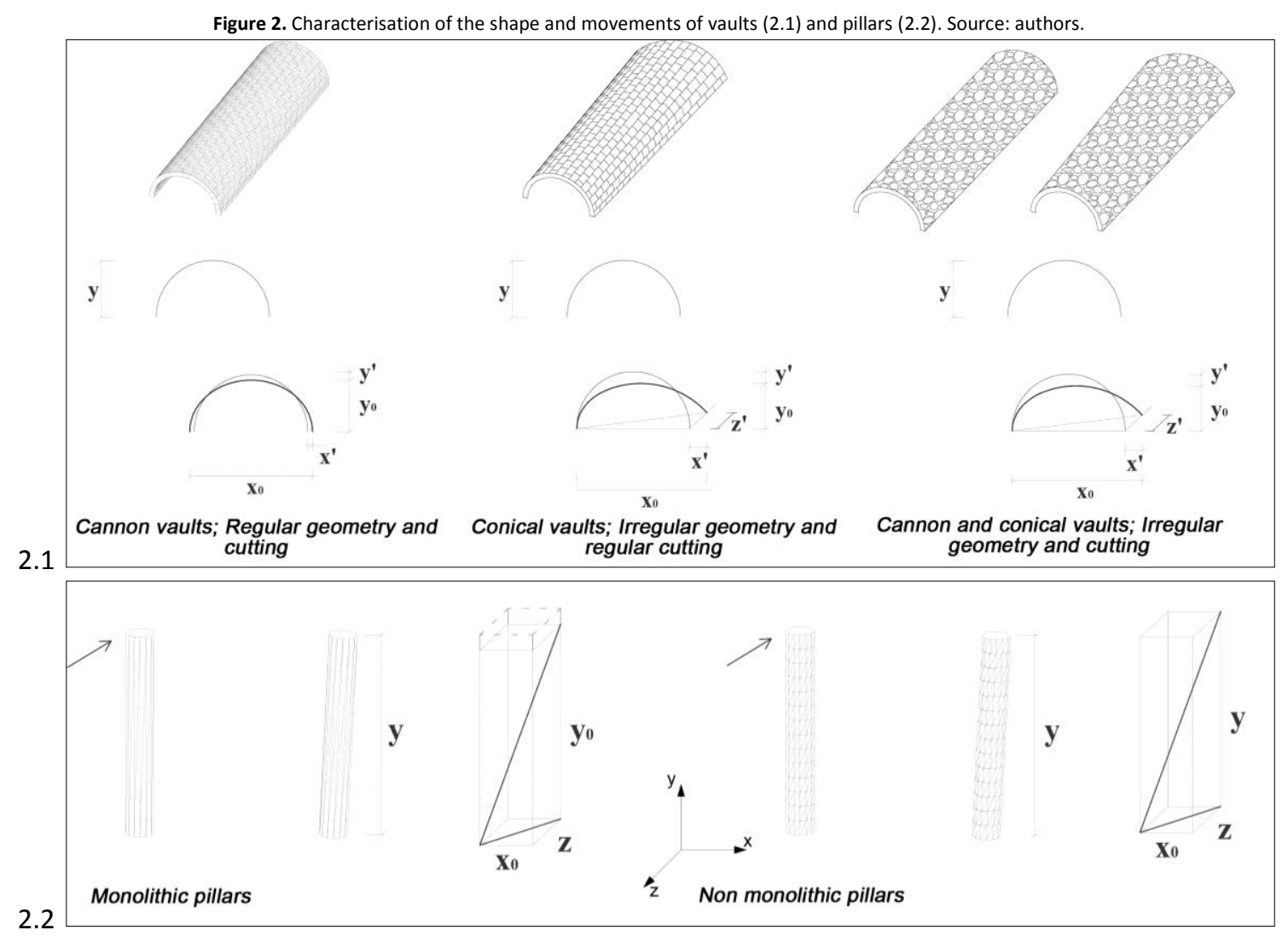

In any or in a combination of the precedent hypotheses, thrusts have two directions $(x, z)$ as long as the supports stand still. Thus, the resultant thrust is not perpendicular to the guideline of the vault (Figure 2.1), and deformations can 
appear on two directions. Vaults thrusts are transmitted to vertical structural elements. The vaults of the central nave are supported by the walls over formerets, which at the same time are supported by the pillars of the central nave. Thus, the vertical elements can deform over the three planes.

The deformations of the pillars are directly related to the stone cutting and mortar of the pillar, and the thrusts received from the irregular shape of the vault. A monolithic, infinitely rigid pillar tends to rotate on its base. The upper part moves over the axis $(x)$ towards the exterior due to the main horizontal thrust with the consequence that there is also movement in the axis (y) since their extreme upper part declines. Finally, there is also movement over axis (z) (Figure 2.2).

If pillars are not monolithic and are built with numerous joints, they tend to deform in the upper part. If we suppose that the extremes of the vaults have not suffered differential settlements and that the movement of these extremes is thus $(\Delta y=0)$, then the deformations are $d f_{p}\left(d f_{p x}, 0, d f_{p z}\right)$, which is the hypothesis of the present case study. There can be a combination of rotations and translations

\section{The geometrical assessment of the pillars}

The assessment is based on a three-dimensional model of the church os Santa María de Arties (Figure 3) obtained with a terrestrial laser scanner (TLS). It is a contactless, non-invasive surveying technique that makes it possible the massive capture of geometric and radiometric data of a given surface (Pesci, Bonali, Galli, \& Boschi, 2012). Thus, it allows a quick and easy capture of the geometry of objects. The main limitations lie in the management of dense point clouds, the texturization of surfaces and the need to place the device in a stable position. In addition, cost is a very important limiting factor (Lluis i Ginovart, Costa-Jover, Coll-Pla S., \& Puche Fontanilles, 2016).

Figure 3. Santa María de Arties. Planimetry and section planes. Source: authors.

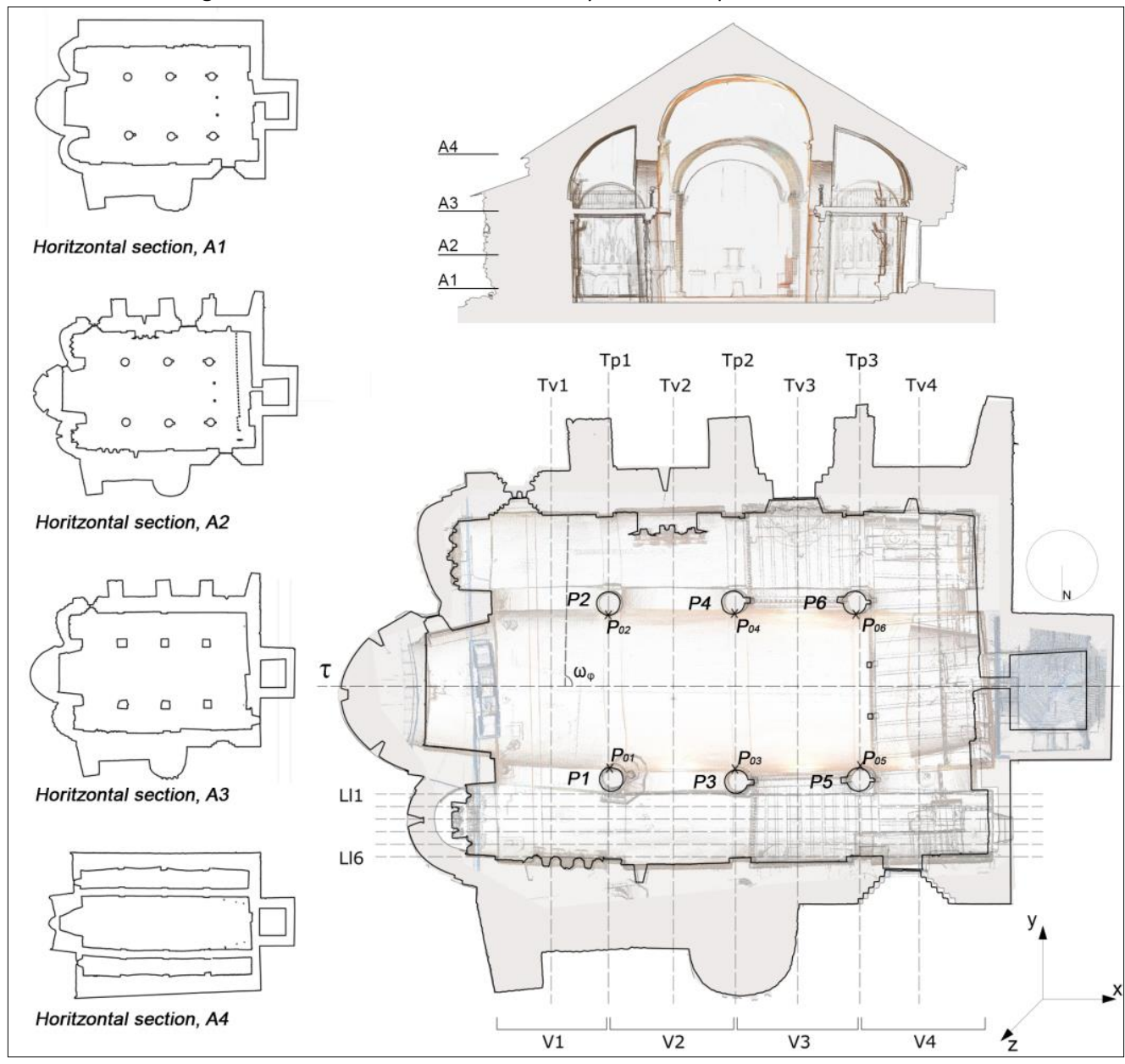

The scanner used is a Leica ScanStation P20, with a bandwidth of $808 / 658$, class 1 . The scanning ratio is $1,000,000$ points, and the noise at 100 is $9.0 \mathrm{~mm}$ for black surfaces, $4.30 \mathrm{~mm}$ for grey surfaces, and $1.5 \mathrm{~mm}$ for white surfaces. The field 
of view is $360^{\circ}$ horizontal and $270^{\circ}$ vertical. The point cloud is processed with the specific software Cyclone, and after the program 3DReshaper is used to obtain the three-dimensional mesh with an average distance of points of $5 \mathrm{~cm}$, as well as a measure of the triangle for detecting $10 \mathrm{~cm}$ holes. The model of the interior of the building has 80.582 points and 156.449 triangles, and the exterior has 314.650 points and 609.472 triangles.

The investigation methodology focuses on the assessment of the geometrical characteristics of the 6 pillars $\left[P_{1} \ldots P_{6}\right]$ with the objective of studying the displacements that they have suffered (Lluis i Ginovart, Costa, \& Coll, 2016). The pillars of the central nave have deformed in a specific way, namely, through the masonry joints $\left(n_{s}\right)$. These joints are perfectly visible on pillars $P_{3}, P_{4}, P_{5}$ and $P_{6}$, while they are more difficult to see on $P_{1}$ and $P_{2}$ since these pillars are partially covered by mural paintings. The measurement of the displacements suffered by the masonry has to deal with the non-monolithic behaviour of the pillars, so the displacements are not linear along their entire length.

The procedure is based on slicing the pillars on $\left(n_{s}\right)$ rows. Thus, the displacement of each pillar can be deduced according to the coordinates of the centroid of each row $\left(x_{c i}, y_{c i}, z_{c i}\right)$, which is calculated from the corresponding polylines through CAD (Computer Aided Design) software.

The centroid of reference $\left(x_{c 0}, y_{c 0}, z_{c 0}\right)$ to quantify the displacements of each row is set in the section of the floor plan since it is considered that it would have not suffered any displacements on $(x)$, and ultimately it defines a common criteria to evaluate pillars displacements. The final section is located at the impost of the pillar $\left(x_{c s}, y_{c s}, Z_{c s}\right)$. The procedure assumes that the original pillars were vertical.

The obtained points makes it possible to deduce the regression plane Pri for each pillar. It is calculated as a function of the $\left(n_{i}\right)$ centroid points of each row. The plane is defined by means of the command "Extract Form" of the program 3DReshaper (www.3dreshaper.com). Thus, the plane that best fits the $\left(n_{i}\right)$ points on each pillar is found. Points are projected perpendicularly over that plane, so it can be defined as a function over plane Pri.

Moreover, it is possible to define a displacement vector contained on each plane $[\operatorname{Pr} 1 . . \operatorname{Pr} 6]$, so the results can be expressed by a vector with coordinates $\left(\mathrm{x}_{\mathrm{i}}, \mathrm{z}_{\mathrm{i}}\right)$. This vector expresses the direction and magnitude of the deformation, so it has a coordinate $(0,0)$ in the base of the pillar and another $\left(x_{d}, z_{d}\right)$ that indicates the displacement of the element. Thus, $\left(x_{d}\right)$ represents horizontal displacement, while $\left(z_{d}\right)$ shows the rotation of the plane in relation to the directrix of the vault. The resultant vector between $(0,0)$ (which is the centroid in the base of the pillar) and $\left(x_{d}, z_{d}\right)$ (which is the centroid of the last row of the pillar) represents the total leaning of the element.

The assessment of this displacement vector determines the clearance angle $(\omega)$ of the regression plane $P_{\mathrm{ri}}$ of the plane over the directrix of the vault $(\tau)$ (Figure 2 ). Thus, this angle can be understood as:

a) $\quad(\omega \phi)=90^{\circ}$, perpendicular to the directrix $\phi_{1}$,

b) $\quad(\omega \phi)<90^{\circ}$, displacement towards the apse,

c) $\quad\left(\omega_{\phi}\right)>90^{\circ}$, displacement towards the façade.

The data obtained characterizes the general tendency of the deformation of the vaults supported by the pillars. The reparation and containment of these deformations are the cause of the reinforcement of the perimeter walls by means of the construction of buttresses or strategical placement of bell towers, which are usually built in the façade opposite to the apse.

Results

\section{Assessment of the pillars of Santa María de Arties}

The assessment of the morphological characteristics of the pillars (Figure 4) is made through the visible elements, such as the masonry joints. Non-visible elements are not considered. Thus, data are obtained according to the centroids of each visible row. Thus, pillars has following rows: $\left(P_{1}=26\right),\left(P_{2}=26\right),\left(P_{3}=27\right),\left(P_{4}=25\right),\left(P_{5}=23\right)$ and $\left(P_{6}=23\right)$. Rows are numbered from bottom to top.

The values of the area, perimeter and height do not show important differences between pillars (Table 1) and (Table 2). The arithmetic mean of the areas (Table 1 ) is $0.693 \mathrm{~m}^{2}$, with a range between $\left[\mathrm{P}_{1}, \mathrm{P}_{4}\right]$ of $[0.731,0.678]$ and a coefficient of variation (from here on C.V.) of $2.77 \%$, so the area of the pillars can be considered to be homogeneous in general terms. The arithmetic mean of the perimeter is $2,981 \mathrm{~m}$, with a range between $\left[\mathrm{P}_{1}, \mathrm{P}_{6}\right]$ of $[3.060,2.950]$ and a C.V. of 
1.45\%. In conclusion, the sections of pillars $\mathrm{P}_{1}$ and $\mathrm{P}_{2}$, located in the heading of the church, are slightly larger than the rest.

In respect to height (Table 2), the arithmetic mean is $3.840 \mathrm{~m}$, as measured over the current wood floor, and the values have a range of [4.170, 3.587]. There is a slight inclination of the floor towards the presbytery, so pillars by pair are comparably of the same height. Thus, the arithmetic mean of $\left[\mathrm{P}_{1}, \mathrm{P}_{2}\right]$ is $4.055 \mathrm{~m}$, with a C.V. of $4.01 \%$, for pillars $\left[\mathrm{P}_{3}, \mathrm{P}_{4}\right]$, the arithmetic mean is $3.829 \mathrm{~m}$, with a C.V. of $2.18 \%$, and finally, for pillars [ $\left.\mathrm{P}_{5}, \mathrm{P}_{6}\right]$, the arithmetic mean is $3.636 \mathrm{~m}$, with a C.V. of $1.89 \%$.

Table 1. Morphologic characteristics of the pillars Pi. Area and perimeter. Source: authors.

\begin{tabular}{|c|c|c|c|c|c|c|c|c|c|c|c|c|}
\hline \multirow{2}{*}{$\begin{array}{l}\text { Pillars } \\
\text { Rows }\end{array}$} & \multicolumn{2}{|c|}{ Pillar 1} & \multicolumn{2}{|c|}{ Pillar 2} & \multicolumn{2}{|c|}{ Pillar 3} & \multicolumn{2}{|c|}{ Pillar 4} & \multicolumn{2}{|c|}{ Pillar 5} & \multicolumn{2}{|c|}{ Pillar 6} \\
\hline & $\begin{array}{l}\text { Area } \\
\left(\mathrm{m}^{2}\right)\end{array}$ & $\begin{array}{c}\text { Perim. } \\
(\mathrm{m})\end{array}$ & $\begin{array}{l}\text { Area } \\
\left(\mathrm{m}^{2}\right)\end{array}$ & $\begin{array}{c}\text { Perim. } \\
(\mathrm{m})\end{array}$ & $\begin{array}{l}\text { Area } \\
\left(\mathrm{m}^{2}\right)\end{array}$ & $\begin{array}{c}\text { Perim. } \\
(\mathrm{m})\end{array}$ & $\begin{array}{l}\text { Area } \\
\left(\mathrm{m}^{2}\right)\end{array}$ & $\begin{array}{c}\text { Perim. } \\
(\mathrm{m})\end{array}$ & $\begin{array}{l}\text { Area } \\
\left(\mathrm{m}^{2}\right)\end{array}$ & $\begin{array}{c}\text { Perim. } \\
(\mathrm{m})\end{array}$ & $\begin{array}{l}\text { Area } \\
\left(\mathrm{m}^{2}\right)\end{array}$ & $\begin{array}{c}\text { Perim. } \\
(\mathrm{m})\end{array}$ \\
\hline 28 & - & - & - & - & - & - & - & - & - & - & - & - \\
\hline 27 & - & - & - & - & 0.695 & 2.992 & - & - & - & - & - & - \\
\hline 26 & 0.989 & 3.932 & 0.708 & 3.059 & 0.697 & 2.977 & - & - & - & - & - & - \\
\hline 25 & 0.745 & 3.086 & 0.700 & 2.974 & 0.707 & 2.994 & 0.670 & 2.907 & - & - & - & - \\
\hline 24 & 0.735 & 3.050 & 0.690 & 2.953 & 0.696 & 2.968 & 0.677 & 2.955 & - & - & - & - \\
\hline 23 & 0.735 & 3.057 & 0.697 & 2.971 & 0.693 & 2.966 & 0.677 & 2.939 & 0.678 & 2.938 & 0.678 & 2.947 \\
\hline 22 & 0.737 & 3.053 & 0.696 & 2.972 & 0.698 & 2.975 & 0.674 & 2.952 & 0.682 & 2.937 & 0.676 & 3.002 \\
\hline 21 & 0.738 & 3.057 & 0.693 & 2.961 & 0.693 & 2.958 & 0.675 & 2.951 & 0.691 & 2.981 & 0.674 & 3.073 \\
\hline 20 & 0.731 & 3.045 & 0.692 & 3.039 & 0.687 & 2.952 & 0.682 & 2.979 & 0.683 & 3.011 & 0.675 & 2.924 \\
\hline 19 & 0.733 & 3.070 & 0.690 & 3.053 & 0.688 & 2.954 & 0.669 & 2.948 & 0.693 & 2.978 & 0.675 & 2.923 \\
\hline 18 & 0.732 & 3.054 & 0.691 & 3.026 & 0.686 & 2.950 & 0.673 & 2.918 & 0.690 & 2.962 & 0.678 & 2.932 \\
\hline 17 & 0.725 & 3.045 & 0.693 & 3.047 & 0.688 & 2.952 & 0.678 & 2.963 & 0.689 & 2.957 & 0.678 & 2.996 \\
\hline 16 & 0.718 & 3.007 & 0.691 & 2.955 & 0.681 & 2.939 & 0.681 & 2.955 & 0.696 & 2.971 & 0.678 & 2.930 \\
\hline 15 & 0.739 & 3.059 & 0.708 & 2.992 & 0.680 & 2.938 & 0.681 & 2.969 & 0.694 & 2.965 & 0.679 & 2.931 \\
\hline 14 & 0.715 & 3.018 & 0.714 & 3.005 & 0.682 & 2.942 & 0.681 & 2.962 & 0.700 & 2.983 & 0.678 & 2.930 \\
\hline 13 & 0.711 & 3.008 & 0.712 & 2.999 & 0.681 & 2.938 & 0.684 & 2.958 & 0.701 & 2.992 & 0.680 & 2.936 \\
\hline 12 & 0.718 & 3.014 & 0.709 & 3.087 & 0.687 & 2.946 & 0.683 & 2.961 & 0.692 & 2.959 & 0.679 & 2.933 \\
\hline 11 & 0.728 & 3.038 & 0.702 & 3.048 & 0.683 & 2.940 & 0.680 & 2.953 & 0.685 & 2.947 & 0.677 & 2.927 \\
\hline 10 & 0.728 & 3.041 & 0.700 & 3.006 & 0.687 & 2.949 & 0.679 & 2.968 & 0.685 & 2.947 & 0.684 & 2.944 \\
\hline 9 & 0.715 & 3.011 & 0.687 & 3.022 & 0.685 & 2.959 & 0.675 & 2.947 & 0.677 & 2.937 & 0.683 & 2.938 \\
\hline 8 & 0.720 & 3.031 & 0.694 & 3.033 & 0.686 & 2.945 & 0.672 & 2.981 & 0.683 & 2.964 & 0.683 & 2.940 \\
\hline 7 & 0.715 & 3.022 & 0.696 & 3.057 & 0.685 & 2.945 & 0.674 & 2.953 & 0.685 & 2.944 & 0.680 & 2.973 \\
\hline 6 & 0.702 & 2.995 & 0.690 & 3.018 & 0.686 & 2.955 & 0.672 & 2.937 & 0.684 & 2.937 & 0.682 & 2.936 \\
\hline 5 & 0.707 & 3.001 & 0.681 & 2.932 & 0.684 & 2.942 & 0.678 & 2.963 & 0.681 & 2.943 & 0.680 & 2.938 \\
\hline 4 & 0.702 & 2.980 & 0.686 & 2.944 & 0.685 & 2.956 & 0.680 & 2.970 & 0.685 & 2.948 & 0.691 & 2.961 \\
\hline 3 & 0.699 & 2.978 & 0.686 & 2.995 & 0.684 & 2.944 & 0.682 & 2.961 & 0.691 & 2.972 & 0.676 & 2.927 \\
\hline 2 & 0.690 & 2.958 & 0.686 & 3.010 & 0.689 & 2.958 & 0.686 & 2.971 & 0.696 & 2.974 & 0.687 & 2.953 \\
\hline 1 & 0.689 & 2.958 & 0.669 & 2.919 & 0.688 & 2.952 & 0.685 & 2.969 & 0.711 & 3.002 & 0.692 & 2.964 \\
\hline Max. & 0.989 & 3.932 & 0.714 & 3.087 & 0.707 & 2.994 & 0.686 & 2.981 & 0.711 & 3.011 & 0.692 & 3.073 \\
\hline Min. & 0.689 & 2.958 & 0.669 & 2.919 & 0.680 & 2.938 & 0.669 & 2.907 & 0.677 & 2.937 & 0.674 & 2.923 \\
\hline Aver. & 0.731 & 3.060 & 0.695 & 3.003 & 0.688 & 2.955 & 0.678 & 2.956 & 0.689 & 2.963 & 0.680 & 2.950 \\
\hline
\end{tabular}

In terms of the sterotomy of the Stone (Table 2), it is possible to identify the entire stone cutting by means of the mortar joints of pillars $P_{3}, P_{4}, P_{5}$ and $P_{6}$, while in $P_{1}$ and $P_{2}$, this is not possible since these pillars are partially covered by a stucco with mural paintings. Points $\mathrm{P}_{0 i}$ are defined as the reference for setting the height of the rows. These are located in the line perpendicular to plane $(\tau)$, which defines the axis of the central nave (Figure 3 ).

Horizontal joints, which define the rows, are generally visible in all pillars $\mathrm{P}_{\mathrm{i}}$. Only visible rows were taken into account for statistical treatment, and the first joint over the wood flooring, which is not original, were not considered. Thus, the assessment, identified a total number of 147 joints.

The pillars of the first structural line $\left[\mathrm{P}_{1}, \mathrm{P}_{2}\right]$ have 26 rows; the second $\left[\mathrm{P}_{3}, \mathrm{P}_{4}\right]$ have 25 and 27 rows, respectively; and those of line $\left[P_{5}, P_{6}\right]$ have 22 and 23 rows. The height of the rows ranges from $[0.311,0.071]$ in pillars $P_{5}$ and $P_{3}$, 
respectively. The mean of the range is $(0.191 \mathrm{~m})$, so there are 20 pieces that have a measurement that is only larger than $13.60 \%$ of all the rows. There are 39 rows between [0.119-0.141 m], which amounts to $20.47 \%$, and $51.02 \%$ are between [0.119-0.161 m].

Table 2. Height of each row and the number of pieces per row. *We cannot measure the number of pieces per row because these pillars are stuccoed. However, given the results from the previous pillars, we can calculate an average of 7.97 pieces/row. Source: authors.

\begin{tabular}{|c|c|c|c|c|c|c|c|c|c|c|c|c|}
\hline \multirow{2}{*}{$\begin{array}{l}\text { Pillars } \\
\text { Rows }\end{array}$} & \multicolumn{2}{|c|}{ Pillar 1} & \multicolumn{2}{|c|}{ Pillar 2} & \multicolumn{2}{|c|}{ Pillar 3} & \multicolumn{2}{|c|}{ Pillar 4} & \multicolumn{2}{|c|}{ Pillar 5} & \multicolumn{2}{|c|}{ Pillar 6} \\
\hline & $\begin{array}{l}\text { Height } \\
\text { (m) }\end{array}$ & $\begin{array}{c}\text { Pieces } \\
/ \\
\text { Row }\end{array}$ & $\begin{array}{c}\text { Height } \\
\text { (m) }\end{array}$ & $\begin{array}{c}\text { Pieces } \\
/ \\
\text { Row }\end{array}$ & $\begin{array}{l}\text { Height } \\
\text { (m) }\end{array}$ & $\begin{array}{c}\text { Pieces } \\
/ \\
\text { Row }\end{array}$ & $\begin{array}{l}\text { Height } \\
\text { (m) }\end{array}$ & $\begin{array}{c}\text { Pieces } \\
/ \\
\text { Row }\end{array}$ & $\begin{array}{c}\text { Height } \\
\text { (m) }\end{array}$ & $\begin{array}{c}\text { Pieces } \\
/ \\
\text { Row }\end{array}$ & $\begin{array}{l}\text { Height } \\
\text { (m) }\end{array}$ & $\begin{array}{c}\text { Pieces } \\
/ \\
\text { Row }\end{array}$ \\
\hline 28 & - & - & - & - & - & - & - & - & - & - & - & - \\
\hline 27 & - & - & - & - & 0.102 & 8 & - & - & - & - & - & - \\
\hline 26 & 0.135 & & 0.479 & & 0.123 & 7 & - & - & - & - & - & - \\
\hline 25 & 0.197 & & 0.140 & & 0.231 & 8 & 0.182 & 7 & - & - & - & - \\
\hline 24 & 0.109 & & 0.100 & & 0.132 & 9 & 0.193 & 9 & - & - & - & - \\
\hline 23 & 0.163 & & 0.100 & & 0.114 & 8 & 0.148 & 7 & 0.063 & 9 & 0.176 & 7 \\
\hline 22 & 0.102 & & 0.130 & & 0.170 & 8 & 0.154 & 6 & 0.111 & 9 & 0.196 & 7 \\
\hline 21 & 0.141 & & 0.120 & & 0.156 & 9 & 0.129 & 9 & 0.214 & 8 & 0.139 & 9 \\
\hline 20 & 0.118 & & 0.120 & & 0.153 & 8 & 0.219 & 7 & 0.131 & 8 & 0.196 & 7 \\
\hline 19 & 0.172 & & 0.130 & & 0.095 & 7 & 0.122 & 9 & 0.187 & 8 & 0.147 & 7 \\
\hline 18 & 0.162 & & 0.140 & & 0.109 & 9 & 0.161 & 8 & 0.164 & 10 & 0.122 & 8 \\
\hline 17 & 0.131 & & 0.110 & & 0.177 & 8 & 0.122 & 9 & 0.147 & 9 & 0.155 & 8 \\
\hline 16 & 0.129 & & 0.160 & & 0.071 & 9 & 0.090 & 9 & 0.221 & 9 & 0.154 & 7 \\
\hline 15 & 0.181 & & 0.200 & & 0.164 & 9 & 0.141 & 8 & 0.157 & 8 & 0.180 & 9 \\
\hline 14 & 0.130 & & 0.130 & & 0.174 & 9 & 0.161 & 9 & 0.203 & 8 & 0.163 & 8 \\
\hline 13 & 0.155 & & 0.130 & & 0.150 & 8 & 0.130 & 9 & 0.159 & 8 & 0.159 & 8 \\
\hline 12 & 0.153 & * & 0.110 & * & 0.170 & 9 & 0.148 & 8 & 0.124 & 7 & 0.175 & 7 \\
\hline 11 & 0.159 & & 0.160 & & 0.125 & 8 & 0.122 & 7 & 0.148 & 8 & 0.160 & 7 \\
\hline 10 & 0.182 & & 0.150 & & 0.125 & 8 & 0.154 & 8 & 0.163 & 8 & 0.151 & 8 \\
\hline 9 & 0.191 & & 0.100 & & 0.122 & 7 & 0.193 & 7 & 0.109 & 7 & 0.130 & 9 \\
\hline 8 & 0.309 & & 0.140 & & 0.139 & 11 & 0.148 & 8 & 0.140 & 9 & 0.151 & 9 \\
\hline 7 & 0.148 & & 0.100 & & 0.137 & 8 & 0.161 & 7 & 0.171 & 7 & 0.147 & 8 \\
\hline 6 & 0.121 & & 0.190 & & 0.140 & 9 & 0.135 & 7 & 0.192 & 6 & 0.187 & 7 \\
\hline 5 & 0.159 & & 0.130 & & 0.226 & 8 & 0.174 & 8 & 0.173 & 7 & 0.102 & 6 \\
\hline 4 & 0.124 & & 0.155 & & 0.125 & 9 & 0.116 & 7 & 0.182 & 8 & 0.220 & 9 \\
\hline 3 & 0.144 & & 0.090 & & 0.192 & 8 & 0.167 & 9 & 0.119 & 7 & 0.118 & 8 \\
\hline 2 & 0.153 & & 0.232 & & 0.185 & 6 & 0.116 & 8 & 0.165 & 7 & 0.220 & 9 \\
\hline 1 & 0.066 & & 0.071 & & 0.081 & 8 & 0.181 & 8 & 0.146 & 6 & 0.137 & 8 \\
\hline Max. & 0.309 & - & 0.479 & - & 0.231 & 11.00 & 0.219 & 9.00 & 0.221 & 10.00 & 0.220 & 9.00 \\
\hline Min. & 0.066 & - & 0.071 & - & 0.071 & 6.00 & 0.090 & 6.00 & 0.063 & 6.00 & 0.102 & 6.00 \\
\hline $\begin{array}{l}\text { Averag } \\
\mathrm{e}\end{array}$ & 0.151 & 7.97 & 0.147 & 7.97 & 0.144 & 8.26 & 0.151 & 7.92 & 0.156 & 7.87 & 0.160 & 7.83 \\
\hline
\end{tabular}

A total number of 98 pieces were identified on pillars $P_{3}, P_{4}, P_{5}$ and $P_{6}$ based on the vertical masonry joints, which are very diffuse. The range of pieces per row is [6-11] pieces, and these extreme numbers make up only $7.14 \%$ of the overall stone cutting. The rows with six pieces are $\mathrm{P}_{3} .2, \mathrm{P}_{4} .22, \mathrm{P}_{5} .1, \mathrm{P}_{5} .6$ and $\mathrm{P}_{6.5}$, and the only row with eleven pieces is $\mathrm{P}_{3} .8$. The average number of pieces per row is 8 , which amounts to $38.78 \%$ of the total number. There are 9 pieces in $28.57 \%$ of the rows and 7 pieces in $25.51 \%$ of the rows. Thus, rows tend to be built with a number of pieces between 7 and 9 , which collectively amount to $92.86 \%$.

These values cause the pillars to have a low stiffness and, therefore, they have a great capacity to deform under the active thrust $\left(E_{b a}\right)$ of the vaults through the transverse and former arches. These are also sensitive to the reaction of the walls and the buttressing system. 


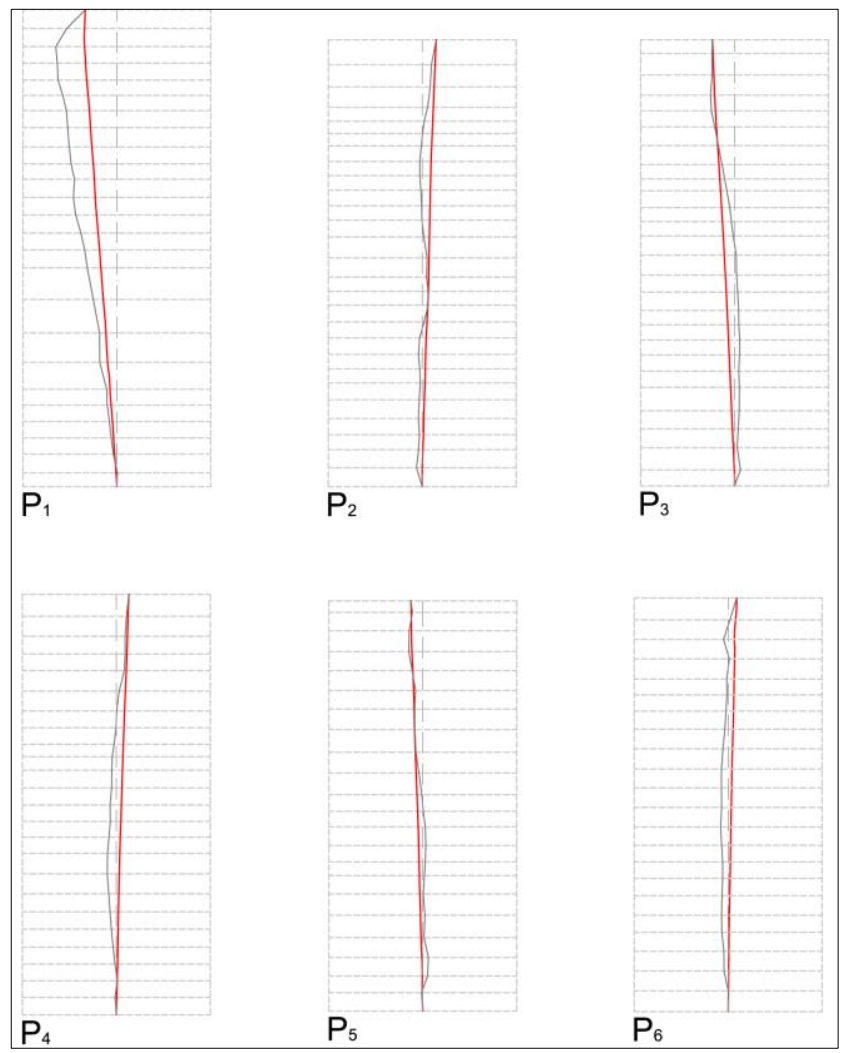

About the assessment of the regression planes Pri of each pillar, vector $\left(x_{i}, y_{i}\right)$ contained in the regression plane $P_{r i}$ shows the displacement of the elements, where $\left(x_{i}\right)$ represents horizontal displacement. The red line (Figure 4$)$ represents the leaning of each pillar over its corresponding regression plane on the direction $\left(z_{d}\right)$ of maximum displacement. A second line was defined for to visualize the displacements in ( $\left.x_{d}\right)$, applying a multiplier of 10 (Figure 4), which makes it possible to identify the nuances of such displacements. Thus, three modes are identified:

- Maximum displacement in the upper part towards the exterior of the building $\left(P_{1}\right)$.

- Maximum displacement in the central part of the pillar $\left(P_{4}, P_{6}\right)$.

- Variable displacement between the upper part and lower part of the pillar $\left(P_{2}, P_{3}, P_{5}\right)$.

Thus, the projection of the displacements of the centroids over the regression planes is not uniform in relation to the vector of the leaning. The vector can be decomposed to on two vectors, one in the lower part of the pillar, which tends to the central vault, and another, which tends to the exterior of the building. The change occurs at a height that ranges from $[1.587,2.946]$ in $\left[P_{2}, P_{4}\right]$.

The greatest displacement is found in pillar $P_{1}$ (Table 3), with a range of displacement on each row of [0.270, 0.001]. That displacement is followed by that in pillar $\mathrm{P}_{3}$, with a range of $[0.190,0.001]$. The range of displacements of the rest of the pillars is as follows: $P_{2}[0.108,0.002], P_{4}[0.109,0.002], P_{5}[0.101,0.001]$, and finally, the least deformed pillar, $P_{6}$ $[0.065,0.001]$. Thus, pillars $P_{1}, P_{3}$ and $P_{5}$ have greater deformations than the others. These are located in the North face, where a massive buttress of $131.04 \mathrm{~m}^{3}$ was built, which stiffens the structure. The wall at the south face has a volume of $179.91 \mathrm{~m}^{3}$, which was later reinforced with four buttresses of $44.96 \mathrm{~m}^{3}$.

About $\left(\mathrm{z}_{\mathrm{i}}\right)$, it shows the rotation of the plane in relation to the directrix of the vault, and it is represented in the floor plant of (Figure 5). None of the regression planes Pri is perpendicular to the directrix of the central vault. Each one is gently sloped. The angle in $P_{1}$ is $85.466^{\circ}$, so $\left(\omega_{\phi}\right)<90^{\circ}$ (Figure 5). It is also the most inclined pillar $(0.270 \mathrm{~m})$ and is the highest $(4.170 \mathrm{~m})$. The rest of the pillars have angles $(\omega \phi)>90^{\circ}$, with a range $\left[103.893^{\circ}, 126.169^{\circ}\right]:\left[\mathrm{P}_{2} ; 103,893^{\circ}\right],\left[\mathrm{P}_{3}\right.$; $\left.108,665^{\circ}\right],\left[\mathrm{P}_{4} ; 117,245^{\circ}\right],\left[\mathrm{P}_{5} ; 112,066^{\circ}\right]$ and $\left[\mathrm{P}_{6} ; 126,169^{\circ}\right]$. 
Table 3. Characteristics of the displacement vector (the angles refer to the inclination of the vector in respect to the vertical). Source: authors.

\begin{tabular}{|c|c|c|c|c|c|c|}
\hline Pillars & $\begin{array}{c}\text { Max. Disp. X } \\
\text { (m) }\end{array}$ & $\begin{array}{l}\text { Min. Disp. X } \\
(\mathrm{m})\end{array}$ & $\begin{array}{l}\text { Angle } \\
\left({ }^{\circ}\right)\end{array}$ & $\begin{array}{l}\text { Pillar length } \\
\text { (m) }\end{array}$ & $\begin{array}{c}\text { Pilar height } \\
\text { (m) }\end{array}$ & $\begin{array}{c}\text { Angular deviation } \\
\left({ }^{\circ}\right)\end{array}$ \\
\hline P1 & 0.270 & 0.001 & 3.78 & 4.183 & 4.170 & 1.11 \\
\hline P2 & 0.108 & 0.002 & 1.78 & 4.842 & 3.940 & 2.72 \\
\hline P3 & 0.190 & 0.001 & 2.85 & 3.890 & 3.888 & 1.37 \\
\hline P4 & 0.109 & 0.002 & 1.71 & 3.774 & 3.770 & 2.21 \\
\hline P5 & 0.101 & 0.001 & 1.67 & 3.590 & 3.587 & 2.15 \\
\hline P6 & 0.065 & 0.001 & 1.17 & 3.687 & 3.684 & 3.15 \\
\hline Max. & 0.270 & 0.002 & 3.78 & 4.842 & 4.170 & 3.15 \\
\hline Min. & 0.065 & 0.001 & 1.17 & 3.590 & 3.587 & 1.11 \\
\hline Average & 0.141 & 0.001 & 2.16 & 3.994 & 3.84 & 2.12 \\
\hline
\end{tabular}

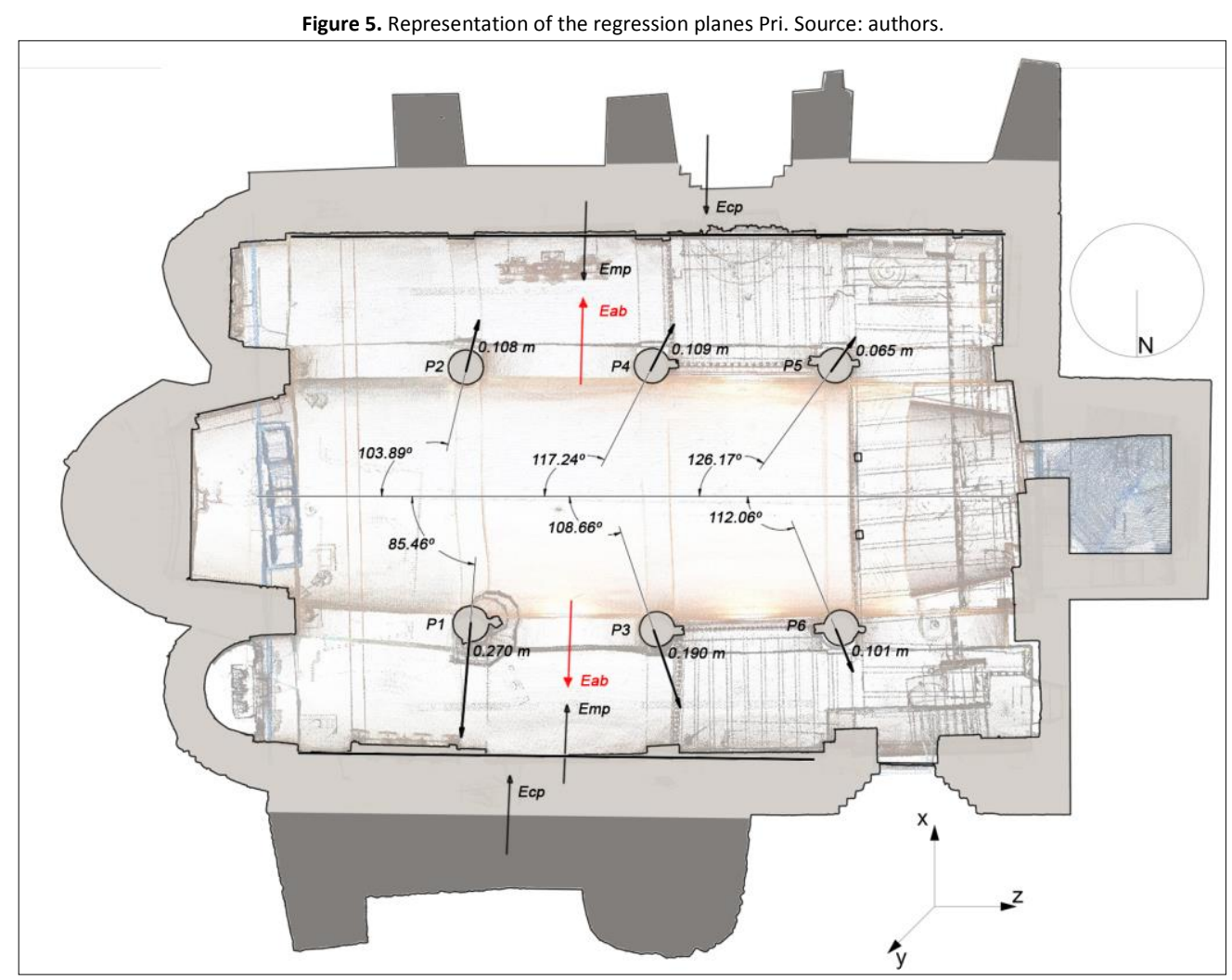

Discussion and Conclusions

The obtained regression planes $P_{r i}$, which contain the deformations for each pillar, tend to have the direction of the thrust over the pillar $\mathrm{Pi}_{\mathrm{i}}$. These displacements are the result of the active thrusts of vaults and the reactions of the buttressing system, walls and buttresses.

This study revealed that the direction of the displacements of the six pillars $\mathrm{P}_{\mathrm{i}}$ is not perpendicular to the central axis of the church $\phi_{1}$ since $\left(\omega_{\phi}\right) \neq 90^{\circ}$. These results proves the hypothesis that the thrusts of the vaults are not perpendicular to the axis of the church, as was the case in Roman vaults, which Choisy (1873) defined with regular geometry and stone cutting. The direction of displacements is caused by the irregular geometry of the vaults of Santa Maria de Arties as well as the masonry stone cutting and the above mentioned effect of the walls and buttresses. The last ones were added to maintain equilibrium during the last millennium.

The displacement of the five pillars $\left(P_{2} \ldots P_{5}\right)$, where $\left(\omega_{\phi}\right)>90^{\circ}$, tends to the opposite façade of the apse. In addition, pillars $P_{5}$ and $P_{6}$, built during twelfth century on that façade, are the least deformed pillars because of two subsequent 
transformations: the construction of the bell tower over the centre of the façade (XIII-XIV) and the wood choir (XVIII). These elements have a stiffening function.

Pillar $\mathrm{P}_{1}$ is the most deformed pillar of Santa Maria de Arties and has $(\omega \phi)<90^{\circ}$ over the main axis. The displacement tends to the apse. This pillar, together with pillar $P_{3}$, where $(\omega \phi)>90^{\circ}$, is located where a great balancing was achieved through the buttressing system. In respect to a specific weight of more than $24 \mathrm{kN} / \mathrm{m}^{3}$, the buttressing system weighs $3144.96 \mathrm{kN}$. This is where funicular shapes have appeared, which are inverted arches. Despite the hanging shape, vaults are thick enough to work under compression strength.

It can be considered that pillar displacements tend to have the same direction of the thrust over pillar $\mathrm{P}_{\mathrm{i}}$. Thus, the regression planes identified $\mathrm{P}_{\mathrm{r}}$, which contain these displacements, are essential to defining any intervention over these masonry buildings because they show the direction of possible preventive actions. The issue is complex and exceeds the initial aims of that investigation, and opens the door to further research on that sense.

Otherwise, the vectorization of the displacements of each row, deduced from the regression plane, makes it possible to parametrize the leaning of each pillar. Three deformation modes were identified, so the displacements of the pillars are not uniform. Moreover, on pillars $\left(P_{2}, P_{3}, P_{5}\right)$, the displacements are variable and appear to be negative displacements on $(x)$ in relation to the vertical. The range of heights has been identified where this change occurs, which is [1.587, 2.946] on $\left[\mathrm{P}_{2}, \mathrm{P}_{4}\right]$, respectively. Although the values are low, this point is of great importance for determining the appropriate actions that need to be taken for intervention on such buildings. Otherwise, no relevant differences has been identified between the pillars displacements of each side that can be related to the two buttressing systems.

Alcolea Blanch, S. (2008). La missió arqueológica del 1907 als Pirineus. Exhibition catalog. Barcelona.

Bassegoda, N. (1972). La Iglesia de Santa María de Arties, barroca y racionalista. Un templo sin cimientos. La Vanguardia Española, p. 51. Barcelona.

Bassegoda, N. (1974). Estética expresionista de la arquitectura románica lombarda en Catalunya como consecuencia de las deformaciones formales y estructurales de las iglesias. In De Re Restauratoria (Vol. Vol II, pp. 33-64). Barcelona: Catedra Gaudi UPB.

Benito, M. A. (2011). La Catedral de Ávila: Evolución constructiva y análisis estructural. PhD thesis. Escuela Técnica Superior de Arquitectura de Madrid. Universidad Politécnica de Madrid.

Bonali, E., Pesci, A., Casula, G., \& Boschi, E. (2014). Deformation of Ancient Buildings inferred by Terrestrial Laser Scanning methodology: the Cantalovo church case study (Northern Italy). Archaeometry, 56(4), 703-716. http://doi.org/10.1111/arcm.12028

Choisy, A. (1873). L'Art de batir chez les Romains. Paris: Ducher et Cie. Retrieved from http://www.academia.edu/9953727/Auguste_Choisy

Choisy, A. (1883). L'art de batir chez les Byzantins. Paris: Librairies de la Sociètè Anonyme de Publications Périodiques.

Costa-Jover, A., Lluis i Ginovart, J., Fortuny-Anguera, G., \& Coll-Pla, S. (2014). Large deformations on a XII Century Romanic church at Val d'Aran (Spain). 9th International Masonry Conference 2014 in Guimarães. Book of Abstracts, 221.

Costa Jover, A., \& Coll Pla, S. (2017). Mecánica de bóvedas de obra de fábrica en las Iglesias del Valle de Arán. Actas Del Décimo Congreso Nacional y Segundo Congreso Internacional Hispanoamericano de Historia de La Construcción, 1.

Dhonju, H., Xiao, W., Shakya, B., Mills, J., \& Sarhosis, V. (2017). Documentation of Heritage Structures Through Geo-Crowdsourcing and Web-Mapping. ISPRS Geospatial Week 2017.

Español, F. (2011). El Pirineu desvetllat: Viatges i descoberta del patrimoni medieval. Annals Del Centre d'Estudis Comarcals Del Ripollès, 7, 13-36.

Granell, E., \& Ramon, A. (2006). Lluís Domènech i Montaner. Viatges per l'arquitectura romànica catalana. Barcelona: Colegio de Arquitectos de Cataluña, España.

Grussenmeyer, P., Landes, T., Voegtle, T., \& Ringle, K. (2008). Comparison methods of terrestrial laser scanning , photogrammetry and tacheometry data for recording of cultural heritage buildings. International Archives of Photogrammetry, Remote Sensing and Spatial Information Sciences, 37 (B5), 213-218.

H. K. Dhonju, W. Xiao, V. Sarhosis, J. P. Mills, S. Wilkinson2 Z. Wang, L. Thapa, U. S. P. (2017). Feasibility study of low-cost image-based heritage documentation in Nepal. Int. Arch. Photogramm. Remote Sens. Spatial Inf. Sci., XLII-2/W3, XLII-2, $237-242$. http://doi.org/https://doi.org/10.5194/isprs-archives-XLII-2-W3-237-2017, 2017

Kadobayashi, R., Kochi, N., Otani, H., \& Furukawa, R. (2004). Comparison and evaluation of laser scanning and photogrammetry and their combined use for digital recording of cultural heritage. Congress of ISPRS, Istanbul 12-23 July. International Archives of Photogrammetry and Remote Sensign, vol. XXXV, part B5, p. 401-406. 
Lluis i Ginovart, J., Costa-Jover, A., Coll-Pla S., \& Puche Fontanilles, J. M. (2016). Techniques of massive data capture: A comparative approach for the assessment of complex spaces in architectural heritatge. Revista de la Contrucción, 15(1), 42-50.

Lluis i Ginovart, J., Costa, A., \& Coll, S. (2016). Glèises en Encurnanclinc de voutes Esgarramingades. Tarragona: EAR. Universitat Rovira i Virgili. Institut Estudis Llerdencs.

Pesci, A., Bonali, E., Galli, C., \& Boschi, E. (2012). Laser scanning and digital imaging for the investigation of an ancient building: Palazzo d'Accursio study case (Bologna, Italy). Journal of Cultural Heritage, 13(2), 215-220. http://doi.org/10.1016/j.culher.2011.09.004

Polo, C. (2009). Santa Maria d'Arties (Naut Aran, Val d'Aran): Un exemple integrau a nivèu de restauracion d'un monument a compdar des entresenhes arqueologiques. Cicle de Conferències Patrimoni Arqueològic I Arquitectònic a Les Terres de Lleida 2009, Departament de Cultura I Mitjans de Comunicacó.p. 75-103.

Puig i Cadafalch, J. (1901). HIstoria General del Arte. Escrita y editada en vista de los monumentos y de las mejores obras publicadas hasta el día, bajo la dirección dels arquitecto Don José Puig i Cadafach. Barcelona: Montaner y Simón Editores.

Puig i Cadafalch, J. (1908). Les iglesies romàniques amb cobertes de fusta de les Valls De Bohí y d'Aran. Anuari de l'Institut d'Estudis Catalans, MCMVII 119-136.

Quagliarini, E., Clini, P., \& Ripanti, M. (2016). Fast, low cost and safe methodology for the assessment of the state of conservation of historical buildings from 3D laser scanning: The case study of Santa Maria in Portonovo (Italy). Journal of Cultural Heritage. https://doi.org/10.1016/j.culher.2016.10.006

Saez. (1976). Primera fase del proyecto de restauración de la Iglesia de Santa María de Artíes en el Valle de Arán (Lérida). Cuadernos de Arquitectura Y Urbanismo, 116, 63-71.

Sternberg, H. (2006). Deformation measurements at historical buildings with terrestrial laserscanners. IAPRS Volume XXXVI, Part 5, Dresden 25-27 September. p. 303-308.

Vendrell, M., Giráldez, P., González, R., Cavallé, F., \& Roca, P. (2008). Santa Maria del Mar. Estudi històric-constructiu, materials de construcció i estabilitat estructural. Barcelona: UB-Patrimoni, Veclus, UPC.

Villanueva, J. L. (1974). “Las bóvedas de cañon.” In De Re Restauratoria Vol. II, 145-158). Barcelona: UPB.

Viollet-le-Duc, E. E. (1868). Dictionaire raisonné de l'architecture française du XIe au XVIe siècle (Vol. III). Paris: B. Bance (A. Morel).

Yilmaz, H. M., Yakar, M., Gulec, S. a., \& Dulgerler, O. N. (2007). Importance of digital close-range photogrammetry in documentation of cultural heritage. Journal of Cultural Heritage, 8(4), 428-433. http://doi.org/10.1016/j.culher.2007.07.004 